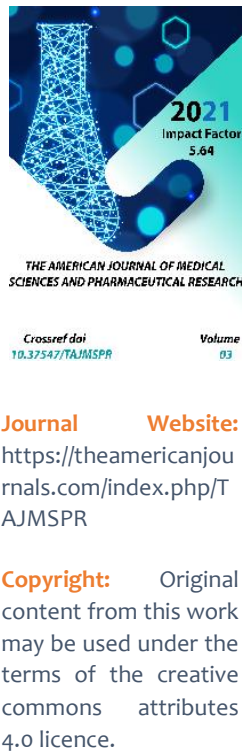

\section{Histological Appearance Of The Liver In Experimental Injury}

\author{
Alimbay Kamalovich Mangitov \\ Chief Physician Of The Sanatorium Zangiota Zam-Zam, Dermatovenerologist, Uzbekistan \\ Rajabbay Israilovich Israilov \\ Director Of The Republican Center For Pathological Anatomy, Doctor Of Medical Science, \\ Professor, Uzbekistan
}

Kamiljan Abdukarimovich Yuldashev

Republican Specialized Scientific And Practical Medical Center For Dermatovenereology And Cosmetology Doctor Of Medical Science, Professor, Uzbekistan

\title{
ABSTRACT
}

In this work, the morphofunctional state has been studied at various times after the simulation of experimental syphilis. It is noted that discirculatory and dystrophic changes develop in the early stages of the study. The appearance of focal and massive necrosis of hepatocytes is accompanied by the development of an inflammatory process in the form of lymphoid infiltration around necrosis and hypertrophy of Kupffer cells. Subsequently, lymphohistiocytic infiltration spreads along the portal tracts, in which plasma cells and eosinophils appear, which are characteristic of syphilitic inflammation.

\section{KEYWORDS}

Experiment, syphilis, hepatitis, morphology, hepatocyte, venereology.

\section{INTRODUCTION}

Despite the significant progress achieved in recent years in preventing the spread of sexually transmitted infections, the incidence rate, especially among young people, remains high $[3,12]$. The worldwide spread of syphilitic infection remains a serious public health problem. Of more than 20 sexually transmitted infections, syphilis is the most controlled [9]. More than 1 million patients with sexually transmitted infections are registered in Russia annually, of which more than 270 thousand are patients with syphilis [1,2,4]. In Uzbekistan, according to the Research Institute of Dermatology and Venereology, 2071 patients with all forms of syphilis were registered in 2012, or 6.9 per 100,000 population. Annual control of sexually transmitted infections is ensured by epidemiological control. In recent years, there has been a structural redistribution of clinical forms of syphilis with 
an increase in the number of epidemiologically dangerous early latent forms, as well as late forms of infection, among which the growth of neuro- and visceral syphilis with manifest clinical manifestations, as well as the number of cases of congenital syphilis, is becoming more noticeable [6-9.13]. The increase in the number of patients with latent syphilis is an urgent problem all over the world.

Syphilitic lesions can develop in any internal organ. They are inflammatory or dystrophic in nature, asymptomatic or manifested by various functional disorders, less often they acquire a clinically pronounced character. Syphilis is considered one of the unrecognized etiological causes of liver dysfunction. The incidence of syphilitic hepatitis is currently unknown. A retrospective study of the causative agents of liver dysfunction in the diagnosis of early syphilis was carried out. The study revealed liver enzyme disorders in $44(39 \%)$ patients with early syphilis, while $3(2.7 \%)$ patients were diagnosed with syphilitic hepatitis.

Syphilitic liver damage is observed in various variants, due to the localization of the proliferative process and its nodular or diffuse nature. In accordance with the classification of Myasnikov (1981), the following clinical varieties are distinguished among chronic syphilitic hepatitis: syphilitic chronic epithelial hepatitis, chronic interstitial hepatitis, miliary gummy hepatitis and limited gummy hepatitis. The earliest changes in liver function that occur in the secondary period of syphilis can be manifested by icterus of the sclera and skin, pruritus and other symptoms of acute syphilitic hepatitis [18-21,24]. As a result of rational antisyphilitic treatment, and even in the absence of specific treatment, syphilitic hepatitis resolves, leaving an altered cellular reactivity. During this period, there may be some casuistic combinations of hepatitis with damage to other organs $[16,22]$. The simultaneous occurrence of acute nephrosis and hepatitis in secondary syphilis is rare [23].

Chronic syphilitic interstitial hepatitis develops as a result of diffuse-proliferative damage to the cells of the interstitial tissue. Just like epithelial hepatitis, it can form even in the secondary period as a result of the direct penetration of pale treponemas. However, interstitial hepatitis can also be infectious and allergic in nature. For a long time, even a small number of pale treponemas, sharply changes the reactivity of the cells of the interstitial tissue, and in the tertiary period, interstitial hepatitis of a productive-infiltrative nature, accompanied by necrosis phenomena, is formed again.

Macroscopically the liver is enlarged, very dense, yellow-brown or whitish-brown in color - the so-called flint liver. Histological changes in the liver are divided into three types. At the first, cellular infiltration of the capsule, periportal connective tissue, walls of the hepatic veins and bile ducts is determined. The infiltrate consists of histiocytes, plasma and lymphoid cells, eosinophilic leukocytes. There is a slight proliferation of Kupffer cells. The second type of changes includes the thickening and infiltration of the glisson capsule, the proliferation of connective tissue in the lobules, and the expansion of the portal tracts. Liver lesions of syphilitic etiology occur both in the early and late stages of the disease. The incidence of syphilis has increased significantly in recent years, especially among men. This report emphasizes the need to take into account the diagnosis of early syphilitic hepatitis in all patients with unexplained elevation of liver enzymes and epidemiological data on unsafe sexual contacts [1,21]. 
The attention of researchers is attracted by the problem of the differential diagnosis of liver syphilis. Distinguish early diffuse hepatitis with active fresh syphilis as specific (changes mainly in blood vessels and perivascular tissues) and nonspecific (toxic-allergic) liver damage, as well as a manifestation of mono-relapse due to insufficient or excessive treatment [5,11-15,]. It is considered appropriate to isolate true early liver syphilis, epidemic hepatitis in untreated syphilis and epidemic hepatitis in treated syphilis [17]. Taking into account the above data, in our work, the goal was set: to study morphological changes in the liver at various times after the simulation of experimental syphilis.

\section{MATERIALS AND RESEARCH METHODS}

Pieces of liver of experimental rabbits were fixed in a $10 \%$ solution of neutral formalin for 48 hours, after washing in running water for 2-4 hours, dehydration was carried out in alcohols of increasing concentration and in chloroform, and embedded in paraffin with wax. From paraffin blocks, histological sections with a thickness of 5-8 microns were made, which were stained by the following histological and histochemical methods: for general morphology, hematoxylin and eosin; for the detection of mucopolysaccharides and glycogen by the PIC reaction method; for the detection of collagen fibers by the Van Gieson method.

\section{Hematoxylin-eosin staining}

It is the most common staining method for histological sections. Paraffin sections are dewaxed in chloroform and washed in distilled water, then a solution of hematoxylin is poured onto the sections for 3 minutes. Rinsing in tap water for 10 minutes and sections are stained with eosin from 0.2 to 3 minutes, depending on the thickness of the sections. They are dehydrated in alcohols of ascending concentration, starting from $70^{\circ}$ to $96^{\circ}$, clarified in carbol-xylene, xylene and embedded in balsam. Result: nuclei of cells are stained in blue-violet color, cytoplasm - in pink.

2. Staining with picrofuchsin according to the Van Gieson method.

After dewaxing and washing in water, paraffin sections are placed in freshly prepared Weigert hematoxylin for 3-5 minutes. After thorough rinsing in two portions of tap water, paint in picrofuchsin for 2-3 minutes, then quickly rinse in water for 5-15 seconds. Carry out sections through $96^{\circ}$ alcohol, re-pouring and keeping in it for 1 to 3 minutes. Clarify the sections in carbol-xylene, treat with xylene and put in balsam. Result: nuclei turn black, connective tissue fibers - bright red, muscle and elastic fibers - yellow, nerve fibers - yellowish-gray.

3. Coloring of mucopolysaccharides according to the PIC reaction.

After dewaxing, the sections are rinsed in water and stained for 5-10 minutes. In a freshly filtered $0.1 \%$ solution of alcian alcohol in 3\% acetic acid. Then washed in distilled water and oxidized in $0.5 \%$ aqueous solution of iodic acid for 2-5 minutes. It is treated with Schiff's reagent for 10-15 minutes. They are washed in running water and the nuclei are finished with hematoxylin and after washing in water the sections are dehydrated in alcohols, clarified in xylene and poured into balm.

\section{RESULTS AND ITS DISCUSSION}

As you know, the liver is an organ in which the main metabolism occurs in chronic infections; due to infectious intoxication, biotoxic metabolites are formed in this organ. As a result, the liver becomes the main target and 
various toxic lesions of both parenchymal and stroma-vascular components develop. In syphilis, the main structural components of the liver receive both direct and indirect damaging effects with inhibition of all enzymatic systems. Which are manifested by the development of dystrophic, necrotic, destructive and inflammatory processes. In the early stages of experimental syphilis, the development of parenchymal protein dystrophy in the cytoplasm of hepatocytes, which often covered the central and intermediate zones of the liver lobules, is noted. Hypertrophy of Kupffer cells is noted with the appearance in the cytoplasm of their brown pigment of both lipidogenic and bilirubinogenic origin (Fig. 1). This morphological feature is also a characteristic feature for antimicrobial activation of liver macrophages. At the same time, a large number of lymphohistiocytic cells accumulate in the focus of liver tissue damage, around dystrophic and necrobiotic altered hepatocytes. Syphilitic liver damage has always been accompanied by damage to the portal tracts and their structural components. In our observations, periportal lymphohistiocytic infiltration was almost always encountered, to varying degrees of severity (Fig. 2). Moreover, in the composition of lymphoid infiltration, macrophages, eosinophils and plasma cells were often found. It was noted that lymphoid infiltration was often oriented around necrobiotic foci of the liver parenchyma, around the lymphatic vessels and in the periportal zone.

Thus, in the early periods after the modeling of syphilis, the development of dystrophic changes in the liver parenchyma in the form of vacuolar and hyaline-droplet protein dystrophy of hepatocytes, which are often located in the 3 rd centrilobular functional zone and rarely in the 2nd intermediate functional zone of the liver lobules, was accompanied. On the part of the vascular-stromal component of the liver tissue, the development of periportal lymphoid infiltration with an admixture of macrophages, eosinophils and plasma cells, as well as sometimes the formation of nonspecific granulomas, was noted. Macrophages in the cytoplasm contained large phagocytosed inclusions. Sometimes bundles of connective tissue appeared as part of the lymphoid infiltration.

The results of the morphological examination of the liver on the 14th day of the experiment showed that, in most cases, the persistence of dystrophic changes of a mixed nature is revealed in hepatocytes. In the third functional zone of the liver lobules, the development of protein-vacuolar dystrophy and colliquation necrosis was noted, which manifested itself in the form of massive or centrilobular necrosis (Fig. 3). In the circumference of the necrosis, there is a significant expansion of both the lumen of the sinusoids and the Disse space with a violation of the beam arrangement of hepatocytes. In hepatocytes, the presence of foci of vacuolization of both cytoplasm and nuclei in the form of "empty nuclei" is revealed. Sometimes, discirculatory phenomena were manifested by paralytic expansion of the central vein and central sections of the sinusoids. At the same time, fibrinoid swelling and fibrinoid necrosis with the development of perivascular edema were detected in the wall of these veins. In hepatocytes, the development of hyaline droplet dystrophy, accumulation of lipofuscin pigment and atrophy of nuclear structures in the form of karyopycnosis and karyorrhexis were noted. In the lumen of the sinusoids and the space of 
Disse, single neutrophilic and eosinophilic leukocytes were found.

In the second functional zone of the liver lobules on the side of the sinusoids, there is a paralytic expansion of the lumen, destruction of the wall with pronounced edema of the perisinusoidal space, in some of them single neutrophilic and eosinophilic leukocytes are detected. In this area, hepatocytes on the one hand are compressed by edematous sinusoids, on the other hand they are subjected to vacuole and hyaline-drop dystrophy. The nuclei of these hepatocytes are in a state of karyolysis and karyopycnosis. In the histochemical study for the detection of glycogen by the method of the PIC reaction, a significant decrease in the content of hepatocytes with PIC of a positive red-pink color of the substance was noted. In individual portal tracts, the presence of cellular infiltration is determined, consisting of lymphoid and leukocyte cells (Fig. 4). Which, diffusely infiltrate the periportal connective tissue and in places penetrate the perisinusoidal space. In the space of Disse, single large cells of macrophages are determined, containing phagocytosed inclusions and microorganisms in the cytoplasm. Thus, on the 14th day of the experiment, syphilitic liver damage is morphologically manifested by the development of mixed vacuolar and protein parenchymal dystrophy, with the appearance of foci of centrilobular colliquation necrosis. On the part of the vascular-stromal tissue, there is a plethora of central veins and sinusoids, pronounced edema of the perisinusoidal space. In response to an infectious toxic effect, a small periportal infiltration of a mixed composition of both lymphoid and leukocyte cells develops; hemosiderin deposition is noted in macrophages and in Kupffer's cells.

Morphological examination of the liver at a later date of the experiment showed that the pathomorphological changes that developed both in the parenchyma and in the stroma of the liver are characteristic of chronic infectious toxic hepatitis. In the third functional zone of the liver lobules, a significant decrease in the volume of protein-vacuolar dystrophy was noted. In some lobules of the liver, there is a slight expansion of both the lumen of the sinusoids and the Disse space with a violation of the beam arrangement of hepatocytes. Often, discirculatory phenomena were minimal in the form of a slight expansion of the central vein and central sections of the sinusoids. At the same time, restoration of the basement membrane and fibrous structures of the connective tissue stroma of the liver tissue was detected in the wall of these veins. In hepatocytes, slight development of hyaline droplet dystrophy, accumulation of lipofuscin pigment and atrophy of nuclear structures in the form of karyopyknosis were noted. Necrobiotic dystrophy was observed only in single hepatocytes located near the portal tracts. In the lumen of the sinusoids and in the space of Disse, single lymphoid and plasma cells were found.

In the second functional zone of the liver lobules on the side of the sinusoids, there is a preservation of the expansion of the lumen, with a slight edema of the perisinusoidal space, in some of them single lymphoid cells and macrophages are detected. In this zone, the hepatocytes are almost completely restored with the preservation of the beam arrangement, in them the nuclear structures have a uniform structure and location, the cytoplasm is evenly stained with eosin, which 
indicates the restoration of the structural and functional elements of the liver hepatocytes. In a histochemical study for the detection of glycogen by the method of the PIC reaction, there was a significant increase in the content of hepatocytes PIC of a positive red-pink color of the substance. In individual portal tracts, the presence of cellular infiltration is determined, consisting of lymphoid and plasma cells characteristic of syphilitic infection (Fig. 5).

Thus, syphilitic lesion in the later stages of the study is morphologically manifested by the restoration of the structural and functional components of hepatocytes in almost all parts of the liver lobules. Only local droplet fatty degeneration remains in the periportal zone of the lobules. On the part of the vascular-stromal tissue, the disappearance of edema and disorganization phenomena with the restoration of the basement membrane and fibrous structures of the liver stroma is noted. In response to an infectious effect, a small periportal infiltration of a mixed composition persists: from both lymphoid and leukocyte cells, bilirubin deposition is noted in macrophages and Kupffer cells. The figures below reflect the state of the syphilitic liver of rabbits on days 7, 21 and 35 of experimental syphilis before specific treatment.

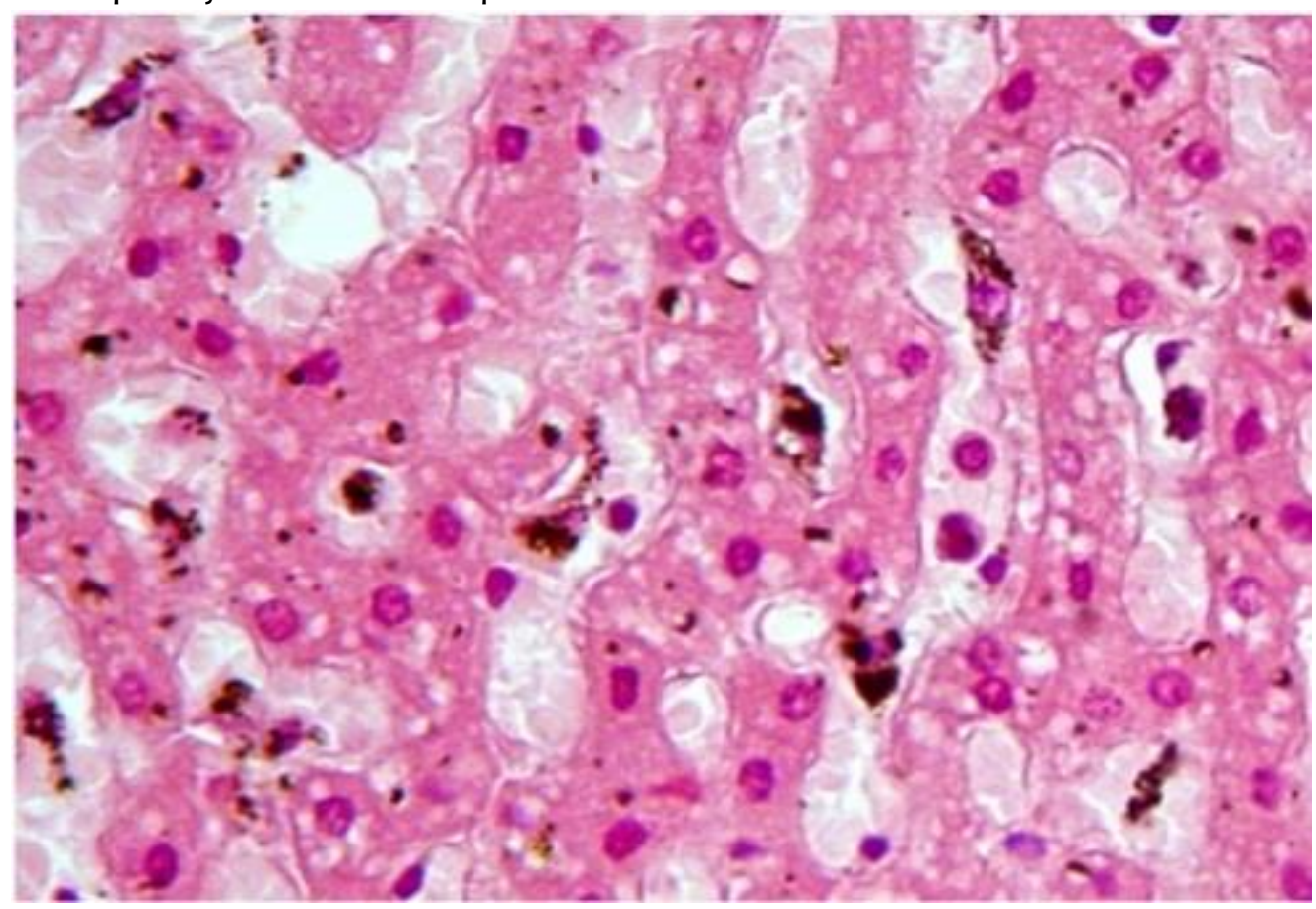

Fig. 1. 7th day of the experiment. Expansion of the Disse space, the appearance of lymphoid cells, hypertrophy of the Kupffer's singing cells. Coloring: hematoxylin and eosin. SW: about 10, rev. 


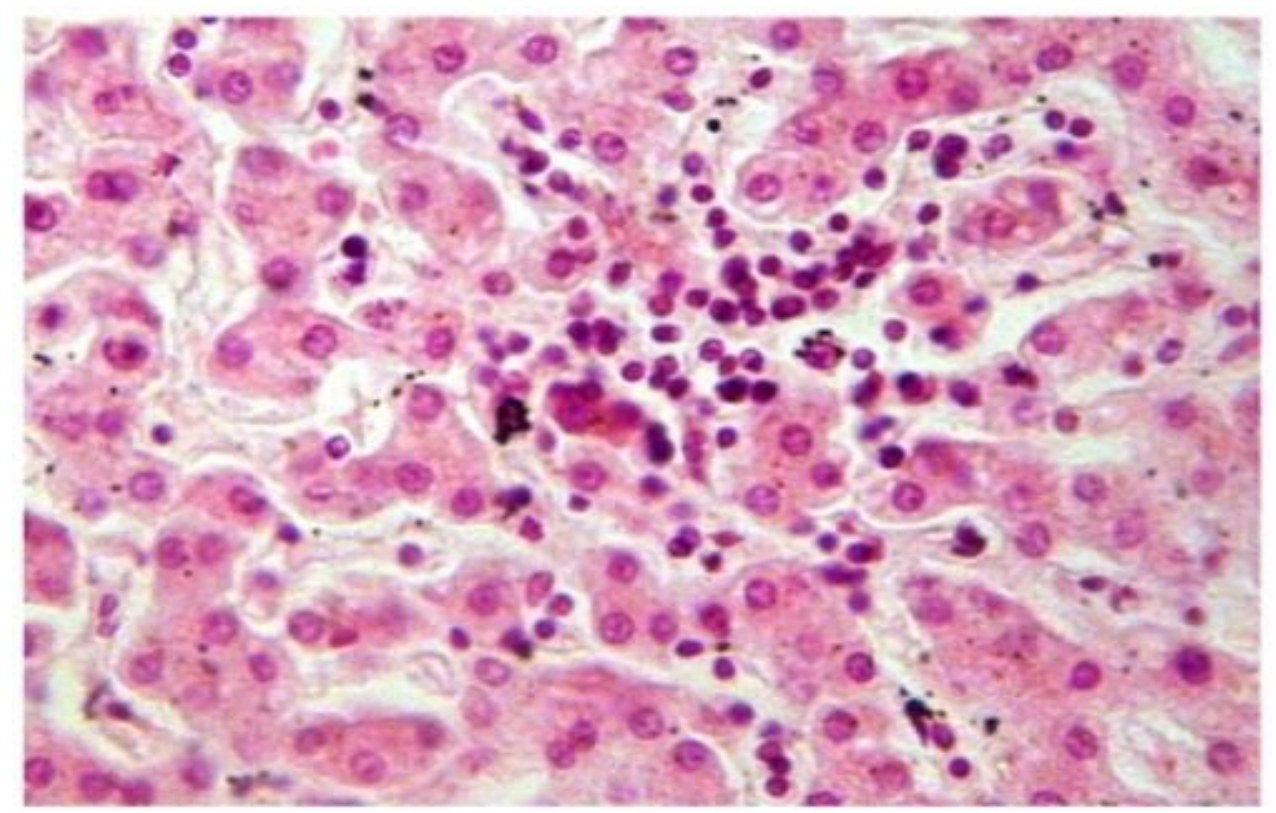

Fig. 2. 7th day of the experiment. Protein and vacuolar degeneration of hepatocytes, accumulation of lymphoid cells around them. Coloring: hematoxylin and eosin. SW: about 10, rev. 40.

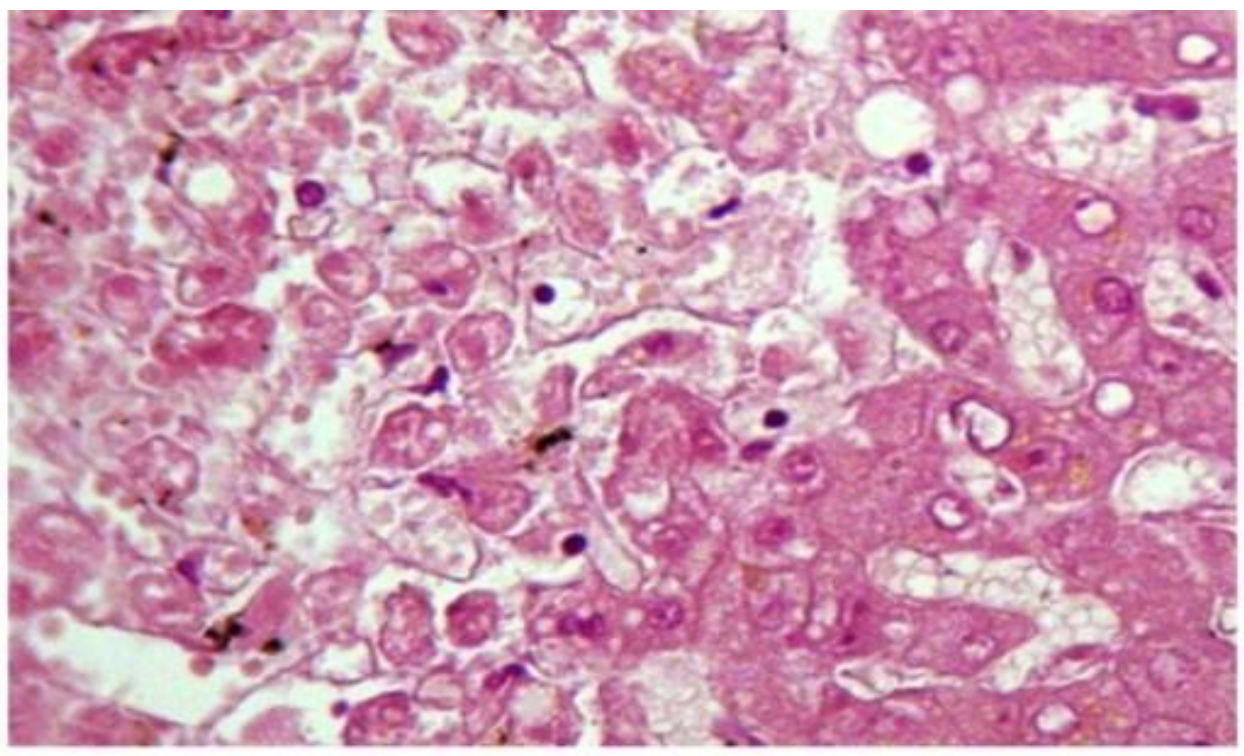

Fig 3. 21 days of the experiment. The appearance of foci of massive necrosis of hepatocytes. Coloring: hematoxylin and eosin. SW: about 10, rev. 40. 


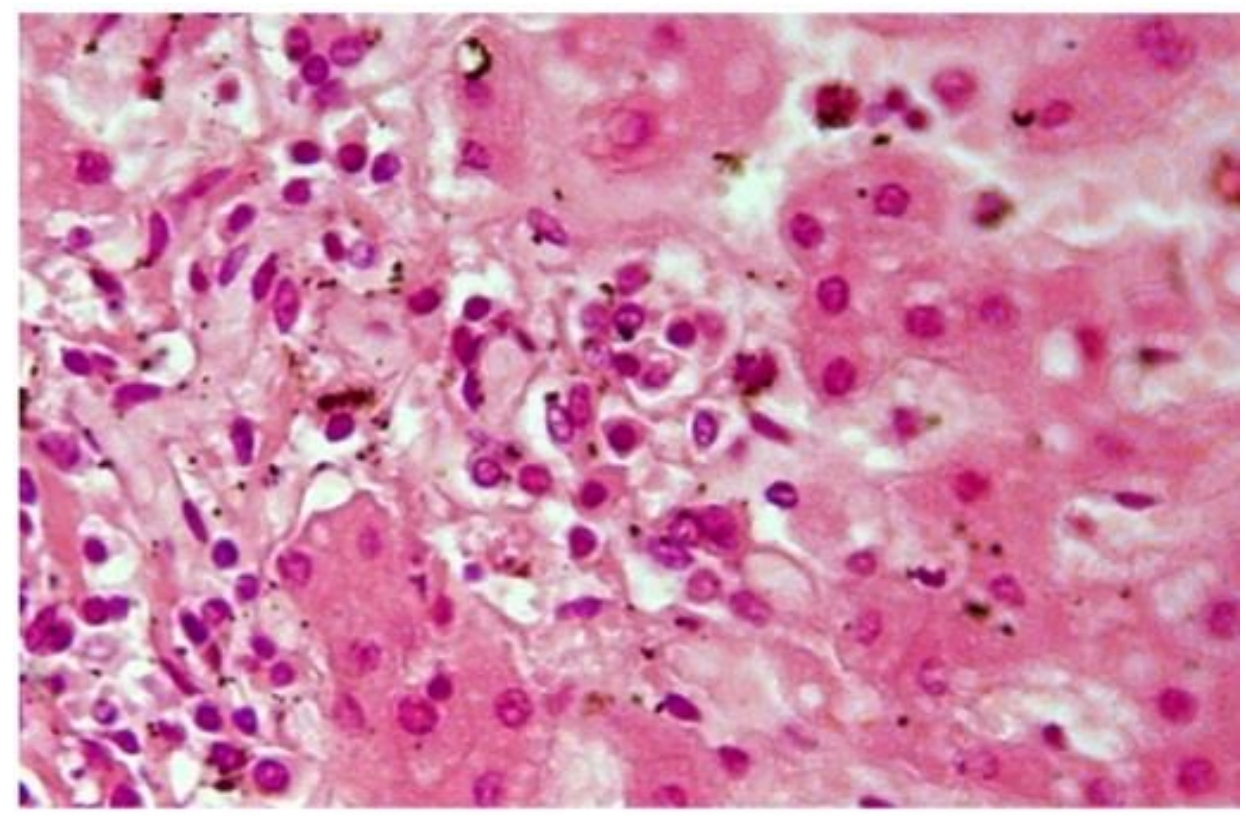

Fig 4. 21 days of the experiment. The appearance of lymphoid infiltration around dystrophically affected hepatocytes. Coloring: hematoxylin and eosin. SW: about 10, rev. 40.

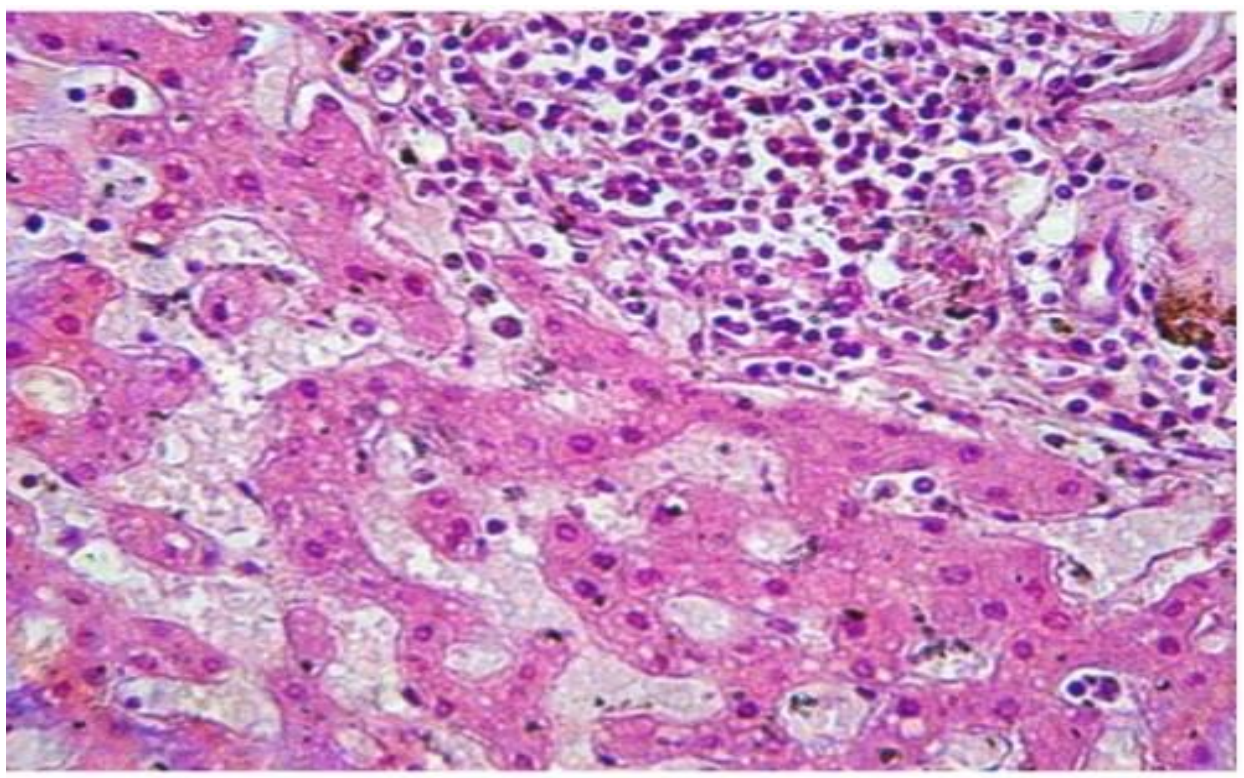

Fig 5.35 day of the experiment. Expansion of the Disse space, protein dystrophy of hepatocytes, diffuse lymphoid infiltration of the portal tracts. Coloring: hematoxylin and eosin. SW: about 10, rev. 40. 


\section{REFERENCES}

1. Баткаев Э.А., Галлярамова Ю.А., Енгоянц Г.М. Инфекции, передаваемые половым путем, и репродуктивное здоровье населения // Рос. журн. кожн. и вен. болезней.- 2003. - №6. с. 39-42.

2. Гладышев В.К. Некоторые особенности клинических проявлений вторичного сифилиса в настоящее время (по данным Ростовского областного кожновенерологического диспансера) I/ Вестн. последиплом. мед. образования. - 2001. - №2. - С. 45

3. Кубанова А.А. Достижения и перспективы изучения Treponema pallidum. / Вестник дерматологии и венерологии. 2006. - №5. - С.34-37.

4. Кулагин, В. И. Полиорганная патология при позднем сифилисе (по материалам патологоанатомического исследования) // Вестник дерматологии и венерологии . - 2001. - №6. - С. 54-55.

5. Мазьянис И.А., Милтиньш А.П,, Карташова О.Я. и др. Структурнофункциональная характеристика печени при ранних стадиях сифилиса // Вестник дерматологии и венерологии.-1980.№1.-С.66-69

6. Мыскин В.С. «Серорезистентность» при сифилисе в практике дерматовенеролога. · // Инфекции, Передаваемые Половым Путем.- 2003. - № 2.—C.24-26.

7. Пожарская В.О. Влияние антигена из очищенных протеинов клеточных структур культуральных бледных трепонем на течение экспериментальной сифилитической инфекции у кроликов : научное издание
I/ Клиническая дерматология и венерология. - Москва, 2010. - №3. - С. 64-69. - Библиогр.: 13 назв.

8. Привалова Н.К. Заболеваемость сифилисом в Российской Федерации: анализ тенденций и прогноз развития эпидемических ситуаций. / Привалова Н.К., Тихонова Л.И. // Инфекции, Передаваемые Половым Путем. - 2000. - №5. - С.35-40.

9. Рашидходжаев Д.Ю. Функциональное состояние печени у больных сифилисом : Тез. докл. / Д.Ю. Рашидходжаев, К.А. Юлдашев, Л.С. Рашидходжаева // Новости дерматол. и венерол. Ташкент, 2002. - №2. - С. 146

10. Рашидходжаев А.Ю. Клинические наблюдения поражений печени при сифилисе : Тез. докл. // Новости дерматол. и венерол. - Ташкент, 2002. №2. - С. 147-148

11. Шинский Г.Е., Коробейникова Э.А,, Ирусов В.В. О функциональном состоянии печени больных ранними формами сифилиса // Вестник дерматологии и венерологии.-1981.№8.-С.31-35

12. Юлдашев, К. А. Специфический гепатит у больной сифилисом вторичным свежим. / К.А. Юлдашев, Ж.Ю. Рашиджоджаев, Ш.А. Тилавбердыев // Новости дерматовенерол. и репродукт. здоровья. - 2004. - №2. - С. 72-73. Библиогр.: 3 назв.

13. Adachi E, Koibuchi T, Okame M, et.al. Liver dysfunction in patients with early syphilis: a retrospective study. // J. Infect. Chemother. 2012. P.- 236-246 
14. Beltrami C, Manfredi R, D'Antuono A, et.al. Sexually-transmitted infections in adolescents and young adults in a large city of Northern Italy: a nine-year prospective survey. // New Microbiol. 2003. Vol. 26. №3. P.- 233-241.

15. Champion $\mathrm{Cl}$, Blanco DR, Lovett MA. Quantitative assessment of protection in experimental syphilis. // Infect Immun. 2005. Vol.73. №9. P.- 5923-5927.

16. Giacani L, Molini BJ, Kim EY, et,al. Antigenic variation in Treponema pallidum: TprK sequence diversity accumulates in response to immune pressure during experimental syphilis. // G. Ital Dermatol Venereol. 2008 , Vol. 143. №1. P.- 79.

17. Guarner J, Greer PW, Bartlett J, et.al. Congenital syphilis in a newborn: an immunopathologic study // Mod Pathol. 1999. Vol. 12. № 1. P.- 82.

18. Keskin S, Sayali E, Keskin E, et al. A case of syphilis investigated due to high liver enzymes. // Turk J. Gastroenterol. 2007 . Vol. 18. №1. P-. 62-63.

19. Kim GH, Kim BU, Lee JH, et,al. Cholestatic hepatitis and thrombocytosis in a secondary syphilis patient. // J. Korean Med Sci. 2010 . Vol. 25. №11. P.- 1661-1664.

20. Leader BT, Godornes C, VanVoorhis WC, Lukehart SA. CD4+ lymphocytes and gamma interferon predominate in local immune responses in early experimental syphilis. // Infect. Immun. 2007 . Vol. 75. №6. P.- 3021-3026.

21. Miura $H$, Nakano $M$, Ryu $T$, Kitamura $S$, Suzaki A. A case of syphilis presenting with initial syphilitic hepatitis and serological recurrence with cerebrospinal abnormality. // Intern Med. 2010. Vol. 49. № 14. P-. 1377-1381.

22. Saito K, Tagawa M, Mimura M, Hasegawa A. Experimental transmission of rabbit syphilis. // J. Vet Med Sci. 2005 Jan. Vol. 67. №1. P.- 79-81.

23. Salazar JC, Rathi A, Michael NL, Radolf JD, Jagodzinski LL. Assessment of the kinetics of Treponema pallidum dissemination into blood and tissues in experimental syphilis by real-time quantitative PCR. // Infect Immun. 2007 . Vol.75. №6. P.- 2954-2958.

24. Tanyel E, Taşdelen Fişgin N, Sarikaya .et al. A case of secondary syphilis with hepatitis. // Mikrobiyol Bul. 2007 . Vol. 41. №2. P.- 291296. 